of patients with amnesia of the Korsakoff type, or that caused by cerebral surgery, have consistently shown bilateral damage to the hippocampus and, at least in cases associated with alcohol, damage to the mamillary bodies and to the dorsomedial nucleus of the thalamus. Mysteriously, transection of the fornix, the main outflow from the hippocampus, does not consistently cause amnesia. The major defect in such amnesic patients is the loss of the ability to transfer material from shortterm to long-term memory. Such incapacity, however, is incomplete even in severe cases; and recall can be aided by cues, hints, and promptings. ${ }^{10}$

The problem of whether short-term and long-term memory are continuous or different in kind is now more or less settled. Most researchers accept the two-component view: a labile short-term memory-the electrical reverberating circuit model is still in favour-and a much more stable long-term memory system. But argument continues about the nature of the permanent trace in the long-term memory. Is it molecular, and does coding occur in RNA, protein, or, as most recently suggested, peptides ?" ${ }^{11}$ The molecular view is supported by, among others, Hydén, ${ }^{3}$ who showed that the retention of a trace from previous excitation was associated with a lasting change in the structure of RNA in cell nuclei. Booth ${ }^{12}$ noted the creation of additional protein within a few minutes of the registration of a memory, and $\operatorname{Richter}^{13}$ pointed out that puromycin, which inhibits protein synthesis, interferes with memory storage and recall.

The other theory is that the permanent trace in long-term memory is more likely to be cellular. Do patterns of repeated excitation lead to structural change in synapses, as suggested by $\mathrm{Hebb}^{14} 30$ years ago ? The growth of new connections in the nervous system is a theory for which no one has produced sound evidence, but the growth of "bigger and better synapses" has received important support. ${ }^{15}$

Both theories leave plenty of room for manoeuvre. According to one biologist, ${ }^{16}$ each large cortical neurone may have more than 10000 synapses on its surface. Another ${ }^{17}$ says that the brain has perhaps $14 \times 10^{9}$ cells, though only one in 10 of these is a neurone. On the other hand, according to Hydén, ${ }^{18}$ there may be $100 \times 10^{9}$ different specific proteins in a human brain, enough to code a lifetime of experiences.

That brings us back to old age and the nature of forgetting, another topic alive with disagreement. Does it happen through simple decay of memory traces with the passage of time or is a more active process-interference-responsible? Such interference with recall could come either from material in the longterm memory or from new material being added-that is, retroactive and proactive interference respectively. ${ }^{19}$

These controversies, though of riveting interest, do not offer the clinician much immediate help with his most common problems. Has perseveration a specific cerebral site, for example, and does nominal dysphasia presage a slow but relentless dilapidation? On their own clinicians have been unable to produce answers to such questions and have had to wait for unhurried evidence from academic research. The steady increase in the numbers of the elderly and of those with dementias of various kinds is adding a note of urgency to the clinician's need for help.

Retired Consultant Psychiatrist,

Alan Norton

Greenwich,

London SE10 8AW

${ }^{1}$ Oakley DA. Brain mechanisms of mammalian memory. Br Med Bull 1981; $37: 175-80$.

2 Luria AR. The working brain: an introduction to neuropsychology. London: Penguin, 1973.
${ }^{3}$ Hydén H. The neuron. In: Brachet J, Mirsky AE, eds. The cell: biochemistry physiology, morphology. Vol 4. New York: Academic Press, 1970:216-323.

${ }^{4}$ McConnell JV, Shigehisa T, Saliva H. Attempts to transfer approach and avoidance responses by RNA injections in rats. In: Pribram KH, Broadbent DE, eds. Biology of memory. New York: Academic Press, 1970:129-59.

5 Penfield W, Erickson TC. Epilepsy and cerebral localisation: a study of the mechanism, treatment and prevention of epileptic seizures. Springfield, Mass: Thomas, 1941.

6 Tulving E. Episodic and semantic memory. In: Tulving E, Donaldson W, eds. Organisation and memory. New York: Academic Press, 1972: 382-403.

7 O'Keefe J, Nadel L. The hippocampus as a cognitive map. Oxford: Clarendon Press, 1978.

${ }^{8}$ Warrington EK. Neuropsychological evidence for multiple memory systems. In: Wolstenhome $\mathrm{G}$, O'Connor $\mathrm{M}$, eds. Brain and mind. Amsterdam: Elsevier, Excerpta Medica, 1979:153-66. (Ciba Foundation Symposium, No 69 (new series).)

${ }^{9}$ Iversen SD. Brain lesions and memory in animals. In: Deutsch JA, ed. The physiological basis of memory. New York: Academic Press, 1973: 305-64.

10 Weiskrantz L. Trying to bridge some neuropsychological gaps between monkey and man. Br f Psychol 1977;68:431-45.

11 Unger G, Oceguera-Navarro C. Transfer of habituation by material extracted from the brain. Nature 1965;207:301-2.

12 Booth DA. Protein synthesis and memory. In Deutsch JA, ed. The physiological basis of memory. New York: Academic Press, 1973:27-58.

13 Richter D. Biochemical aspects of memory. In : Richter D, ed. Aspects of learning and memory. London: Heinemann Medical, 1966:73-99.

14 Hebb DO. The organisation of behaviour: a neuropsychological theory. New York: Wiley, 1949

15 Eccles JC. Quoted by Rosenzweig MR. Evidence for anatomical and chemical changes in the brain during primary learning. In : Pribram KH, Broadbent DE, eds. Biology of memory. New York: Academic Press, 1970:69-85.

16 Young JZ. The memory systems of the brain. London: Oxford University Press, 1966.

17 Smith A. The body. London: Allen and Unwin, 1968.

${ }^{18}$ Hydén H. A molecular basis of neuron-glia interaction. In : Schmitt FO, ed. Macromolecular specificity and biological memory. Cambridge, Mass: MIT Press, 1962:55-69.

19 Baddeley AD. Psychology of memory. New York: Basic Books, 1976.

\section{Alcoholic heart disease}

The association of heart disease with heavy drinking has been recognised for well over a century; the early authorities included William Osler, John MacKenzie, and Graham Steell. ${ }^{1}$ Though nutritional factors such as thiamine deficiency occasionally result in high-output cardiac failure, most alcoholic patients are well nourished ${ }^{2}$ and the alcoholic who "does not eat with his meals" is a rarity. The conviction has therefore grown that alcohol has a direct toxic effect on cardiac muscle-as it has on the liver. Controversy continues on the basis of animal experiments, ${ }^{3}$ but most clinicians today would agree with the prescient statement of Vaquez 60 years ago in his textbook Maladies $d u$ Cour, quoted by Ferrans, ${ }^{1}$ that "alcohol is capable of producing a subacute myocarditis, often misdiagnosed because of the slowness of its evolution and the coexistence in the terminal period of cardiac murmurs and albuminuria, which tend to relate the cardiac insufficiency to a valvular cardiopathy or to renal sclerosis." Classic beriberi ${ }^{4}$ is seldom encountered in Western countries, and the common clinical presentation of the alcoholic with heart disease remains that portrayed by Evans ${ }^{5}$ and Brigden and Robinson. ${ }^{6}$

Alcohol exerts its destructive effect on muscle (skeletal as well as heart ${ }^{7}$ ) by a complex biochemical process that probably starts with a change in the permeability of the cardiac cell to ions such as potassium, phosphate, magnesium, and calcium. The early ultrastructural changes shown by electron microscopy include intracellular oedema, lipid droplets, excess glycogen, abnormal mitochondria, and deranged sarcoplasmic 
reticulum. ${ }^{810}$ Light microscopy ${ }^{11}$ shows no changes that might not occur in other cardiomyopathies; macroscopically, the heart is dilated and hypertrophied.

Invasive studies of the heart in alcoholics ${ }^{12}{ }^{13}$ have shown depression of left ventricular function and reduced cardiac output, while echocardiography has since provided a useful means of non-invasive study of alcoholics both with and without symptoms. Acute depression of cardiac function by alcohol has been found in nomral individuals ${ }^{14} 15$ and in patients with coronary disease, ${ }^{16}$ while disturbed cardiac function or hypertrophy of the left ventricle has been found in chronic alcoholics without cardiac symptoms. ${ }^{17-19}$ In alcoholics who had abstained for a mean of three years function appeared normal ${ }^{20}$ - suggesting that the pathological changes may be reversible. Matthews and colleagues ${ }^{21}$ have recently reported echocardiographic studies on 22 chronic alcoholics without symptoms of heart disease and 11 with congestive cardiomyopathy, using data from 136 normal persons as controls. They found that all patients with symptoms had increased left ventricular systolic and diastolic dimensions and estimated left ventricular mass. Among the symptomless patients two-thirds showed abnormalities in at least one of the variables studied, the most frequent being an increase in left ventricular mass. In the light of earlier studies on the left ventricle ${ }^{22} 23$ Matthews et al have speculated on the stages through which the ventricle may pass as the result of damage by alcohol before the emergence of the typical picture of congestive cardiomyopathy with a dilated, failing ventricle. For example, mild initial dilatation may be accompanied by an increase in the thickness of the wall, so that the ratio of thickness to internal dimension is increased and function remains normal. Further insult results in more dilatation but less thickening of the wall, so that the ratio becomes slightly decreased. Finally, with further dilatation but no change in wall thickness the stress on the wall increases, systolic function is impaired, and decompensation becomes apparent.

At first glance, echocardiographic studies of this kind may seem simple, but in fact they require time, practice, and accuracy and are not available as a prognostic tool for most of the patients at risk. With alcoholism a growing problem in Britain $^{24}$ alcoholic heart disease may be expected to increase. Physicians must therefore be alert to the diagnosis in any patient who presents with cardiac failure without one of the common underlying pathological causes, especially if atrial fibrillation is present. ${ }^{6}$ We must accept that alcohol is a potential myocardial poison, though the precise biochemical means by which it exerts its toxic effects is not yet clear. For the busy clinician the mechanism is not of paramount importance. His task, so long as man brews alcoholic drinks, must be to make known their dangers to the heart as well as the liver-and to advise abstinence at the first indication of disturbed cardiac function, when the damage may yet be reversed. ${ }^{20} 25$

Consultant Cardiologist,

R W PORTAL

Kingston General Hospital,

Hull HU3 IUR

${ }^{1}$ Ferrans VJ. Alcoholic cardiomyopathy. Am 7 Med Sci 1966;252:89-104.

${ }^{2}$ Regan TJ. Ethyl alcohol and the heart. Circulation $1971 ; 44: 957-63$.

${ }^{3}$ Rossi MA. Alcohol and malnutrition in the pathogenesis of experimental alcoholic cardiomyopathy. 7 Pathol 1980;130:105-16.

4 Wagner PI. Beriberi heart disease. Physiologic data and difficulties in diagnosis. Am Heart $\mathcal{f}$ 1965;69:200-5.

${ }^{5}$ Evans $\mathrm{W}$. The electrocardiogram of alcoholic cardiomyopathy. Br Heart $\mathcal{F}$ $1959 ; 21: 445-56$.

${ }^{6}$ Brigden W, Robinson J. Alcoholic heart disease. Br Med $\mathcal{f} 1964$;ii: 1283-9.
7 Rubin E. Alcoholic myopathy in heart and skeletal muscle. $N$ Engl 7 Med $1979 ; 301: 28-33$.

${ }^{8}$ Hibbs RG, Ferrans VJ, Black WC, Weilbaecher DG, Walsh JJ, Burch GE. Alcoholic cardiomyopathy. An electron microscopic study. $A m$ Heart $\mathcal{7} 1965 ; 69: 766-79$.

${ }^{9}$ Bulloch RT, Pearce MB, Murphy ML, Jenkins BJ, Davis JL. Myocardial lesions in idiopathic and alcoholic cardiomyopathy. Study by ventricular septal biopsy. Am f Cardiol 1972;29:15-25.

"Rubin E, Katz AM, Lieber CS, Stein EP, Puszkin S. Muscle damage produced by chronic alcohol consumption. Am f Pathol 1976;83: 499-515.

${ }^{11}$ Schenk EA, Cohen J. The heart in chronic alcoholism: clinical and pathologic findings. Pathologia et Microbiologia 1970;35:96-104.

12 Regan TJ, Levinson GE, Oldewurtel HA, Frank MJ, Weisse AB, Moschos CB. Ventricular function in noncardiacs with alcoholic fatty liver: role of ethanol in the production of cardiomyopathy. F Clin Invest 1969 48:397-407.

${ }^{13}$ Asokan SK, Frank MJ, Witham AC. Cardiomyopathy without cardiomegaly in alcoholics. Am Heart $\mathcal{7}$ 1972;84:13-8.

${ }^{14}$ Ahmed SS, Levinson GE, Regan TJ. Depression of myocardial contractility with low doses of ethanol in normal man. Circulation 1973 48:378-85.

15 Delgado CE, Fortuin NJ, Ross RS. Acute effects of low doses of alcoho on left ventricular function by echocardiography. Circulation $1975 ; \mathbf{5 1}$ : 535-40.

${ }^{16}$ Conway N. Haemodynamic effects of ethyl alcohol in patients with coronary heart disease. Br Heart $\mathcal{F} 1968 ; 30: 638-44$

17 Spodick DH, Pigott VM, Chirife R. Preclinical cardiac malfunction in chronic alcoholism. Comparison with matched normal controls and with alcoholic cardiomyopathy. N Engl f Med $1972 ; 287: 677-80$.

${ }^{18}$ Levi GF, Quadri A, Ratti S, Basagni M. Preclinical abnormality of left ventricular function in chronic alcoholics. Br Heart 7 1977;39:35-7.

${ }^{19}$ Askanas A, Udoshi M, Sadjadi SA. The heart in chronic alcoholism: a noninvasive study. Am Heart 7 1980;99:9-16.

${ }^{20}$ Reeves WC, Nanda NC, Gramiak R. Echocardiography in chronic alcoholics following prolonged periods of abstinence. Am Heart $\mathscr{f}$ $1978 ; 95: 578-83$.

${ }^{21}$ Matthews EC, Gardin JM, Henry WL, et al. Echocardiographic abnormalities in chronic alcoholics with and without overt congestive heart failure. $A m$ f Cardiol $1981 ; 47: 570-8$.

${ }^{22}$ Grossman W, Jones D, McLaurin LP. Wall stress and patterns of hyper trophy in the human left ventricle. $\mathcal{F}$ Clin Invest $1975 ; 56: 56-64$.

${ }^{23}$ Ford LE. Heart size. Circ Res 1976;39:297-303.

${ }^{24}$ Anonymous. Alcoholism: time for action. $B r$ Med $\mathcal{F} 1981 ; 282: 1177-8$.

${ }^{25}$ Demakis JG, Proskey A, Rahimtoola SH, et al. The natural course of alcoholic cardiomyopathy. Ann Intern Med 1974;80:293-7.

\section{Mechanical intestinal obstruction}

Intestinal obstruction is a common and dangerous surgical emergency. About 1750 deaths from this cause are notified each year in England and Wales, of which 750 are due to strangulated external hernias. Some $80 \%$ of these affect the small bowel. ${ }^{1}$

The causes of the common types of intestinal obstruction have changed quite dramatically during the lifetime of today's senior surgeons. In the first three decades of the century strangulated hernias accounted for a high percentage of cases. Since then the incidence has dropped considerably in the Western world, probably because these hernias have been repaired electively with considerable enthusiasm. By contrast, adhesions have become more and more common owing to the enormous increase in the frequency with which abdominal surgery is now being performed. For example, out of nearly 7000 cases of intestinal obstruction in 21 British hospitals during 1925-30, almost half were due to strangulated hernia and only $7 \%$ to adhesions ${ }^{2}$; but in a series of 1252 cases reported in 1955 and operated on during the previous decade the incidence of adhesions had gone up to $31 \%$, whereas hernias accounted for only $10 \%$ of the cases. ${ }^{3}$ Recently Bizer and his colleagues ${ }^{4}$ have reviewed 405 patients in New York 